\title{
Inhibitory effect of Ginkgol C17:1 on the biological behavior of tumor cells
}

\author{
YUEYING LI ${ }^{1-3}$, JUN LIU ${ }^{2}$, YALI LIU ${ }^{3}$, XIAOMING YANG ${ }^{3}$, BINGZHONG HUANG $^{4}$ and MIN CHEN ${ }^{1}$ \\ Schools of ${ }^{1}$ Medicine; ${ }^{2}$ Life Sciences, and ${ }^{3}$ Food Science and Biological Engineering, \\ Jiangsu University; ${ }^{4}$ Dantu District Hospital, Zhenjiang, Jiangsu 212013, P.R. China
}

Received August 8, 2015; Accepted November 30, 2016

DOI: $10.3892 / \mathrm{ol} .2017 .5664$

\begin{abstract}
Ginkgol C17:1 is a bioactive compound derived from Ginkgo biloba. In the present study, the effect and possible mechanisms of action of Ginkgol C17:1 on the biological behaviors of tumor cells were investigated. Whilst cell proliferation was assessed using the MTT assay, the behaviors of cell migration and invasion were explored using Transwell and modified Transwell assays. The results revealed that Ginkgol C17:1 significantly inhibited the proliferation, migration and invasion of human tumor cells in a dose-dependent manner. Furthermore, due to their associations with the biological behaviors of tumor cells, the protein expression of matrix metalloproteinase (MMP)-7, Ras homolog gene family, member A (RhoA) and phosphorylated-protein kinase B (Akt) was analyzed by western blotting. The results showed that the expression of the aforementioned proteins was decreased markedly following Ginkgol C17:1 treatment. The results of the present study suggested that Ginkgol C17:1 suppresses the biological behaviors of tumor cells by inhibiting the activation of the mitogen-activated protein kinase/MMP, Rho/Rho-associated protein kinase and phosphatidylinositol 3-kinase/Akt signaling pathways.
\end{abstract}

\section{Introduction}

Conventional treatments for the clinical management of cancer include surgery, chemotherapy and radiotherapy. The majority of patients with high-stage cancer or who have undergone tumor surgery require chemotherapy. However, some patients cannot tolerate the treatment or exhibit drug resistance, and

Correspondence to: Dr Xiaoming Yang, School of Food Science and Biological Engineering, Jiangsu University, 301 XueFu Road, Zhenjiang, Jiangsu 212013, P.R. China

E-mail: xm_yang1963@126.com

Dr Min Chen, School of Medicine, Jiangsu University, $301 \mathrm{XueFu}$ Road, Zhenjiang, Jiangsu 212013, P.R. China

E-mail: chenmina88@yahoo.com

Key words: Ginkgol C17:1, tumor cells, proliferation, migration, invasion the efficacy of systemic chemotherapy remains unsatisfactory (1). Only $60-70 \%$ of malignant tumors can be treated with radiotherapy, and certain patients with recurrent or metastatic disease only qualify for palliative treatment due to tolerance to other treatments, complications and/or malignant tumor metastasis $(2,3)$. Other treatment options include immunotherapy and traditional Chinese medicine, including Ginkgol C17:1.

Ginkgols are the active compounds with an anticancer effect from Ginkgo biloba. Three different classes of alkylphenols, including Ginkgolic acids, ginkgols and bilobols (Fig. 1), occur in various parts of Ginkgo biloba. Ginkgols are also termed 3-alkylphenols or cardanols, and their alkyl side chains vary between 13 and 17 carbons in length with 0-2 double bonds (4). Ginkgols have been reported to exhibit a wide range of pharmacological effects, including antibacterial $(5,6)$, antifeeding (7), antioxidant (8) and anti-apoptotic activities, on tumor cells in vitro (9).

Ginkgols are composed of four homolog monomers with different alkyl side chains: C13:0, C15:0, C15:1 and C17:1 (10). Among the ginkgol monomers, Ginkgol C17:1 has been shown to exert the strongest inhibitory effect on cell viability in a number of human cancer cells $(9,11)$.

Ginkgol C17:1 was isolated, purified and identified by the authors of the present study. Considering the results from our previous studies $(9,12)$, the present study aimed to systematically investigate the proliferation, migration and invasion of tumor cells following treatment with various concentrations of Ginkgol C17:1. Furthermore, the present study explored the possible mechanisms of the signaling pathways underlying the effects of Ginkgol C17:1.

\section{Materials and methods}

Cancer cell lines and culture. Human hepatoma carcinoma HepG2 and human colon epithelial carcinoma SW480 cells were obtained from the Institution of Cell Biology of the Chinese Academy of Sciences (Shanghai, China) and cryopreserved at the School of Medicine, Jiangsu University (Zhenjiang, China). The HepG2 and SW480 cells were maintained in Dulbecco's modified Eagle's medium (DMEM) supplemented with $10 \%$ fetal bovine serum (FBS) (both from Gibco; Thermo Fisher Scientific, Inc., Waltham, MA, USA) at $37^{\circ} \mathrm{C}$ in a humidified atmosphere containing $5 \% \mathrm{CO}_{2}$. The 
A

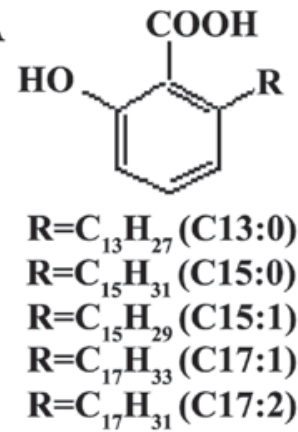

B<smiles>[R]C1CCCC(O)C1</smiles>

$\mathbf{R}=\mathrm{C}_{13} \mathbf{H}_{27}(\mathrm{C} 13: 0)$

$\mathbf{R}=\mathrm{C}_{15} \mathbf{H}_{31}(\mathbf{C 1 5 : 0 )}$

$\mathbf{R}=\mathrm{C}_{15} \mathbf{H}_{29}(\mathbf{C} 15: 1)$

$\mathrm{R}=\mathrm{C}_{17} \mathrm{H}_{33}(\mathrm{C} 17: 1)$
C<smiles>[R]c1cc(O)cc(O)c1</smiles>

$\mathrm{R}=\mathrm{C}_{15} \mathrm{H}_{31}(\mathrm{C} 15: 0)$

Figure 1. Alkyl-phenol compounds in Ginkgo biloba. (A) ginkgolic acid, (B) ginkgol and (C) cardol/bilobol.

medium was changed every 2 days and the cells were maintained at subconfluence.

Reagents. Trypsin-EDTA solution was purchased from Gibco; Thermo Fisher Scientific, Inc. The horseradish peroxidase (HP)-conjugated secondary antibodies, goat anti-mouse polyclonal IgG (cat. no. A0216; dilution, 1:10,000) and goat anti-rabbit polyclonal IgG (cat. no. A0208; dilution, 1:10,000) were purchased from Beyotime Institute of Biotechnology (Haimen, China). The enhanced chemiluminescence (ECL) reagents were bought from GE Healthcare Life Sciences (Chalfont, UK). MTT was purchased from Sigma-Aldrich (Merck Millipore, Darmstadt, Germany). Mouse monoclonal immunoglobulin $\mathrm{G}(\mathrm{IgG})$ anti-as homolog gene family, member A (RhoA; cat. no. sc-418; dilution, 1:1,000) and $\beta$-actin antibody (cat. no. sc-47778; dilution, 1:1,000) were purchased from Santa Cruz Biotechnology, Inc. (Dallas, TX, USA). Polyclonal rat anti-rabbit matrix metalloproteinase (MMP)-7 antibody (cat. no. S247; dilution, 1:1,000) was purchased from Bioworld Technology, Inc. (St. Louis Park, MN, USA). Rabbit polyclonal antibodies against protein kinase B (Akt; cat. no. IM001-0359; dilution, 1:1,000) and phosphorylated (p)-Akt (cat. no. IM001-0270; dilution, 1:1,000) were purchased from ExCel Biology Co., Ltd. (Shanghai, China). Ginkgol C17:1 (high performance liquid chromatography (HPLC) purity of $>96.5 \%$ ) was donated by the School of Food and Biological Engineering, Jiangsu University (7).

MTT assay. The cells were pooled and diluted to a cell density of $10^{5}$ cells $/ \mathrm{ml}$, then dispensed into a 96 -well plate to a final volume of $100 \mu \mathrm{l}$ per well. Following incubation for $12 \mathrm{~h}$ at $37^{\circ} \mathrm{C}$ in $5 \% \mathrm{CO}_{2}$, the cells were treated with various concentrations $(5,10,20,40$ or $80 \mu \mathrm{g} / \mathrm{ml})$ of Ginkgol C17:1in the same final volume of $100 \mu \mathrm{l}$ per well for an extended incubation of $24 \mathrm{~h}$ at $37^{\circ} \mathrm{C}$. A total of $10 \mu \mathrm{l}$ MTT solution $(5 \mathrm{mg} / \mathrm{ml})$ was then added to each well and incubated for another $4 \mathrm{~h}$ at $37^{\circ} \mathrm{C}$. Subsequent to the removal of the growth medium, $100 \mu 1$ dimethyl sulfoxide (DMSO) was added and mixed thoroughly. The absorbance was measured at an optical density of $490 \mathrm{~nm}$ using a microplate reader (Bio-ad Laboratories, Inc., Hercules, CA, USA). Positive (DMEM and 1\% DMSO) and negative controls (DMEM alone) were included in all assays.

Migration assay. A cell migration assay was performed using a Transwell Boyden chamber, with $8.0-\mu \mathrm{m}$ polyethylene terephthalate (PET) membrane 24-well cell culture inserts
(Corning Incorporated, Corning, NY, USA). In total, $500 \mu 1$ DMEM containing $10 \%$ FBS was added to the bottom chamber. Exponential phase HepG2 or SW480 cells were collected, and $5 \times 10^{4}$ cells were seeded into the upper chamber in $300 \mu \mathrm{l}$ serum-free medium containing various concentrations $(20,40$ or $80 \mu \mathrm{g} / \mathrm{ml})$ of Ginkgol C17:1. The cells were allowed to migrate through the PET membrane to the bottom chamber. Following a 24 -h incubation at $37^{\circ} \mathrm{C}$ in $5 \% \mathrm{CO}_{2}$, the cells that had not migrated were removed from the upper chamber using cotton swabs, and the cells that had migrated to the lower side of the membrane were fixed in $4 \%$ paraformaldehyde and stained with Giemsa solution for $10 \mathrm{~min}$. The level of migration was determined by counting the cell numbers under a light microscope at a magnification of $\mathrm{x} 200$. The migrated cells were counted in 5 randomly selected fields per insert, and the mean values were calculated. All experiments were performed in triplicate for each migration condition.

In vitro invasion assay. For the peridium basement membrane preparation, $5 \mathrm{mg} / \mathrm{ml}$ Matrigel (Corning Matrigel basement membrane matrix; cat. no. 356234; Corning Incorporated) was thawed at $4^{\circ} \mathrm{C}$, kept on ice and diluted in cold serum-free DMEM to a final concentration of $1 \mathrm{mg} / \mathrm{ml}$ using pre-cooled pipette tips. A total of $50 \mu \mathrm{l}$ diluted Matrigel was then added to the upper chamber of each pre-cooled Transwell insert. The wells without lids were maintained at $37^{\circ} \mathrm{C}$ for $\sim 2 \mathrm{~h}$ until the Matrigel dried completely. Subsequently, for the hydration basement membrane preparation, gelled Matrigel was gently washed with warm serum-free culture medium, after which $50 \mu 1$ serum-free DMEM medium was added to the Transwell insert. The hydration basement membrane was left at $37^{\circ} \mathrm{C}$ for $30 \mathrm{~min}$. Finally, the assay protocol was the same as described for the cell migration assay.

Western blotting. HepG2 and SW480 cells were cultured with 20,40 or $80 \mu \mathrm{g} / \mathrm{ml}$ Ginkgol C17:1 for $24 \mathrm{~h}$, reached a confluency of $\sim 80 \%$ in the 6 -well plates, they were lysed in lysis buffer (50 mM Tris, $150 \mathrm{mM} \mathrm{NaCl}, 1 \mathrm{mM}$ EDTA and 1\% Triton X-100; pH 7.4), washed three times with cold PBS and treated with $1 \mathrm{mM}$ phenylmethylsulfonyl fluoride (Shanghai Bogoo Biotechnology Co., Ltd., Shanghai, China) for $30 \mathrm{~min}$ on the ice. Following transfer into an Eppendorf tube (Corning Incorporated), centrifugation at 12,000 $\mathrm{x} g$ was performed for $5 \mathrm{~min}$ at $4^{\circ} \mathrm{C}$. Finally, the supernatant was taken as the whole cell protein extract. 

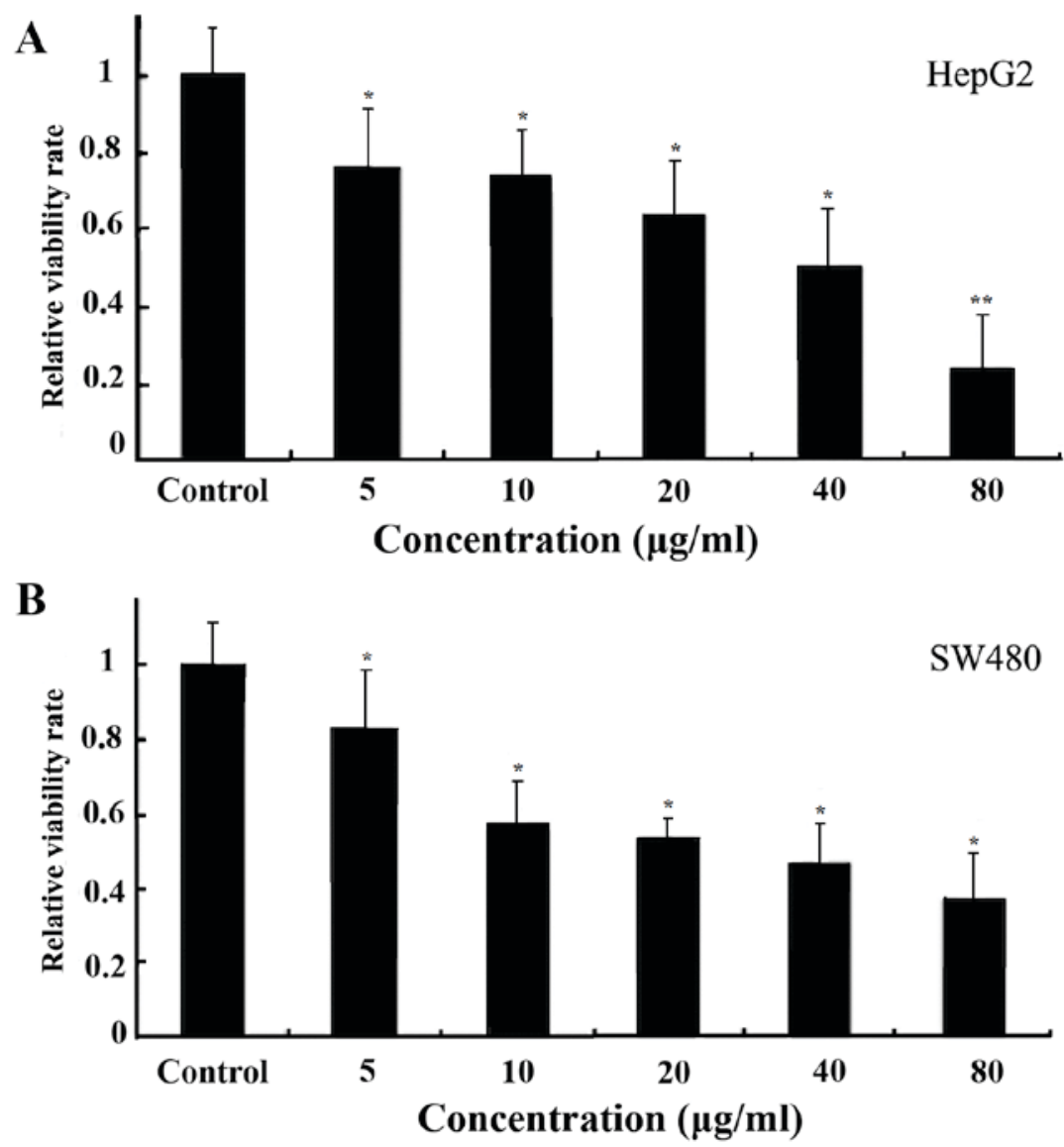

Figure 2. Ginkgol C17:1 reduces tumor cell viability. (A) HepG2 or (B) SW480 cells were treated with dimethyl sulfoxide alone (control) or with 5, 10, 20, 40 or $80 \mu \mathrm{g} / \mathrm{ml}$ Ginkgol C17:1 for $24 \mathrm{~h}$. Cell viability was detected using the MTT assay. Ginkgol C17:1 reduced the cell viability compared with the control group. Data are presented as the mean \pm standard deviation of three independent experiments. ${ }^{*} \mathrm{P}<0.05,{ }^{* *} \mathrm{P}<0.01 \mathrm{vs}$. the control cells.

The sample proteins were run on 10.0 or $12.5 \%$ SDS polyacrylamide gels, and were transferred onto polyvinylidene difluoride (PVDF) membranes (Bio-Rad Laboratories, Inc., USA). The PVDF membranes were initially blocked with $5 \%$ milk in TBS-T $(80 \mathrm{~g} / 1 \mathrm{NaCl}, 2 \mathrm{~g} / 1 \mathrm{KCl}, 30 \mathrm{~g} / 1$ Tris and $0.1 \%$ Tween-20; $\mathrm{pH} 7.4$ ) for $1 \mathrm{~h}$ at room temperature. The membranes were then incubated with the primary antibodies at $4^{\circ} \mathrm{C}$ overnight. Following subsequent incubation of the membranes with HP-conjugated secondary antibodies for $1 \mathrm{~h}$ at room temperature, the ECL reagents were applied to reveal the positive bands on the membrane, according to the protocol of the manufacturer. The bands were detected using the Typhoon 9400 imager (GE Healthcare Life Sciences, Piscataway, NJ, USA).

Statistical analysis. Data are expressed as the mean \pm standard deviation. Statistical analysis was performed with the Student's $t$-test in SPSS 16.0 software (SPSS, Inc., Chicago, IL, USA). An independent samples $t$-test was used to compare the relative cell numbers in the viability, migration and invasion assays. $\mathrm{P}<0.05$ was considered to indicate a statistically significant difference.

\section{Results}

Ginkgol C17:1 reduces the viability of tumor cells. The HepG2 (Fig. 2A) and SW480 (Fig. 2B) cells were treated with
Ginkgol C17:1 for $24 \mathrm{~h}$ at concentrations of 5, 10, 20, 40 or $80 \mu \mathrm{g} / \mathrm{ml}$. Cell viability was detected using the MTT assay. The results revealed that the concentrations of Ginkgol C17:1 exhibited a dose-dependent inhibitory effect on the viability of the cancerous cell lines.

Ginkgol C17:1 suppresses the migration of tumor cells. The effect of Ginkgol C17:1 on the migration of HepG2 (Fig. 3A) and SW480 (Fig. 3B) cells was evaluated using a Transwell Boyden chamber. The cellular migration was induced using $10 \%$ FBS as a chemotactic factor to increase the basal migration of tumor cells in the control group. Treatment of the cells with 20,40 or $80 \mu \mathrm{g} / \mathrm{ml}$ Ginkgol C17:1 for $24 \mathrm{~h}$ exhibited a dose-dependent inhibitory effect on cell migration.

Ginkgol C17:1 suppresses the invasion of tumor cells. The effect of Ginkgol C17:1 on tumor cell invasion was examined using a Matrigel invasion assay with a modified Transwell Boyden chamber. Subsequent to treatment with various concentration of Ginkgol C17:1 for 24 h, the number of HepG2 (Fig. 4A) and SW480 (Fig. 4B) cells that passed through the Matrigel basement membrane matrix was markedly lower compared with the control group, and Ginkgol C17:1 exhibited a dose-dependent inhibitory effect on cancer cell invasion.

Ginkgol C17:1 effects the protein expression of several signaling pathway components. Several signaling pathways, 
A
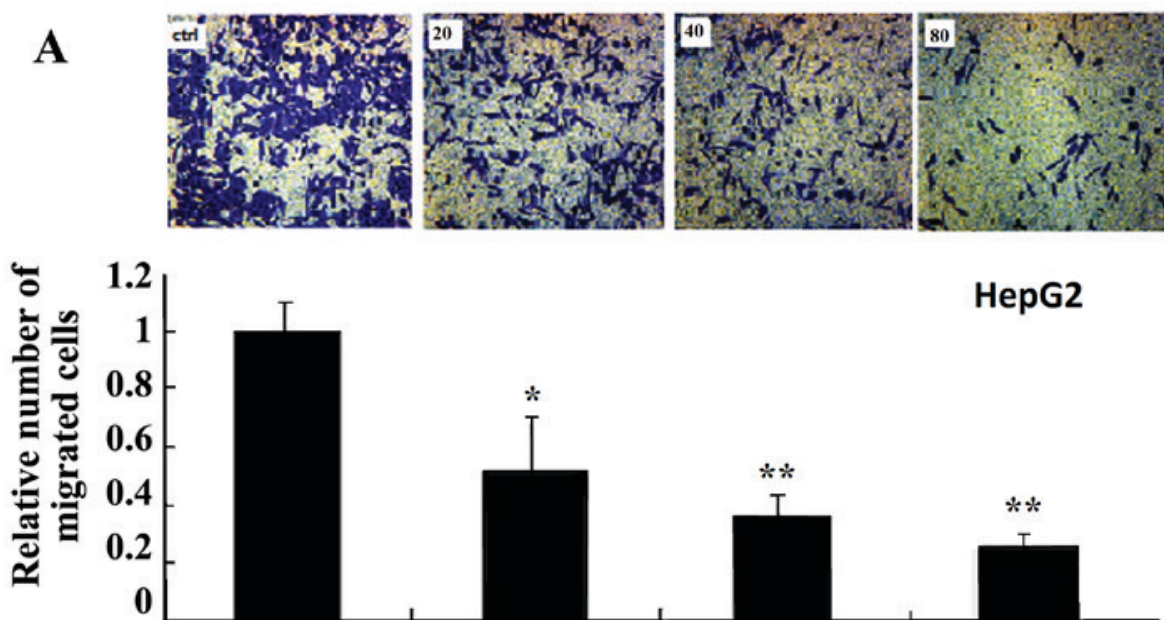

20

$\begin{array}{cc}20 & 40 \\ \text { Concentration }(\mu \mathrm{g} / \mathrm{ml})\end{array}$

HepG2

Control

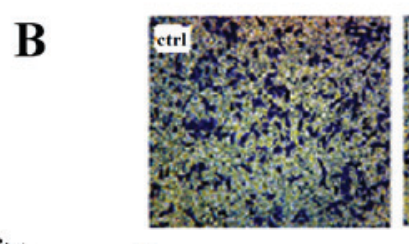

$\ddot{\circ}$
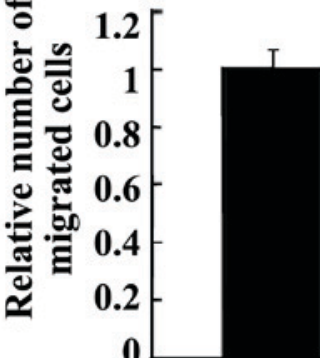
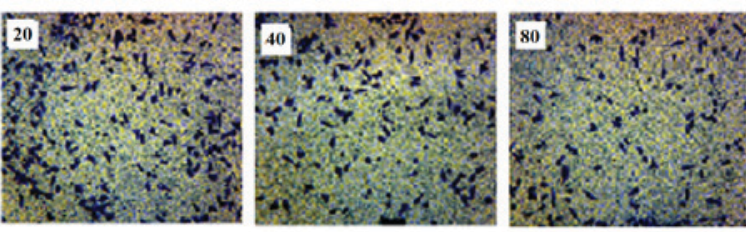

SW480

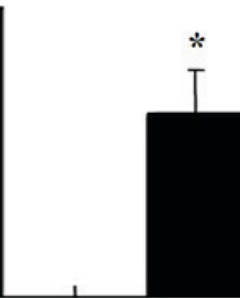

20

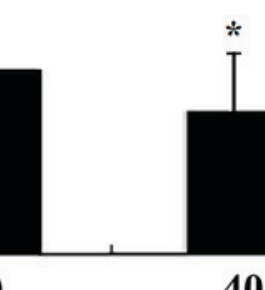

40

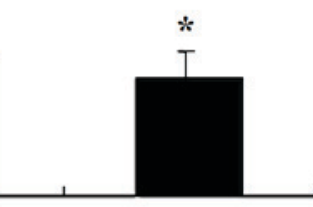

Concentration $(\mu \mathrm{g} / \mathrm{ml})$

Figure 3. Ginkgol C17:1 inhibits cancer cell migration. The migration of (A) HepG2 and (B) SW480 cells was detected using the Transwell assay. Migrated cells were examined under a light microscope (magnification, $\mathrm{x} 200$ ) following treatment with dimethyl sulfoxide alone (control) or various concentrations of Ginkgol C17:1 for $24 \mathrm{~h}$. Data are presented as the mean \pm standard deviation from three independent experiments, each performed in duplicate. ${ }^{*} \mathrm{P}<0.05$, ${ }^{* *} \mathrm{P}<0.01$ vs. the control cells.

including the mitogen-activated protein kinase/extra cellular signal-regulated kinase (EK), reactive oxygen species/EK and phosphatidylinositol 3-kinase (PI3K)/Akt pathways have been reported to be involved in the invasion, metastasis and prognosis of cancer $(13,14)$. However, it remains unknown whether these pathways contribute to the anticancer effects of Ginkgol C17:1. In the present study, the expressions of MMP-7, RhoA, Akt and p-Akt were analyzed by western blotting. Following treatment of HepG2 (Fig. 5A) and SW480 cells (Fig. 5B) with various concentration of Ginkgol C17:1 for $24 \mathrm{~h}$, the total amount of Akt remained the same, while the protein expressions of MMP-7, RhoA and p-Akt were markedly decreased.

\section{Discussion}

Ginkgo biloba L. is the only surviving member of the plant order Ginkgoales and serves as one of the oldest living seed plant groups of medicinal, spiritual and horticultural importance worldwide (15). Studies investigating the antitumor characteristics of ginkgo alkylphenols have focused on ginkgo acids (GAs). Liu and Zeng (16) found that HepG2 cells were more sensitive to the cytotoxicity of GAs than primary rat hepatocytes. GAs significantly inhibited the growth of Hep-2 cells, arrested cells at the G0/G1 phase, decreased the level of B-cell lymphoma 2 (Bcl-2)/Bcl-2-like protein 4 (Bax) (17) and induced the apoptosis of pituitary gland tumor cells by increasing the radiosensitivity of the cells (18).

However, GAs are not stable, but are easily decarboxylated to form ginkgols subsequent to exposure to heat and acid or base catalysis. The Ginkgol C17:1 monomer can be isolated and the structure of the monomer has been confirmed by HPLC-diode array detection, gas chromatography-mass spectrometry, proton nuclear magnetic resonance (NM) and carbon-13-NM analysis (9). Our previous study revealed that 

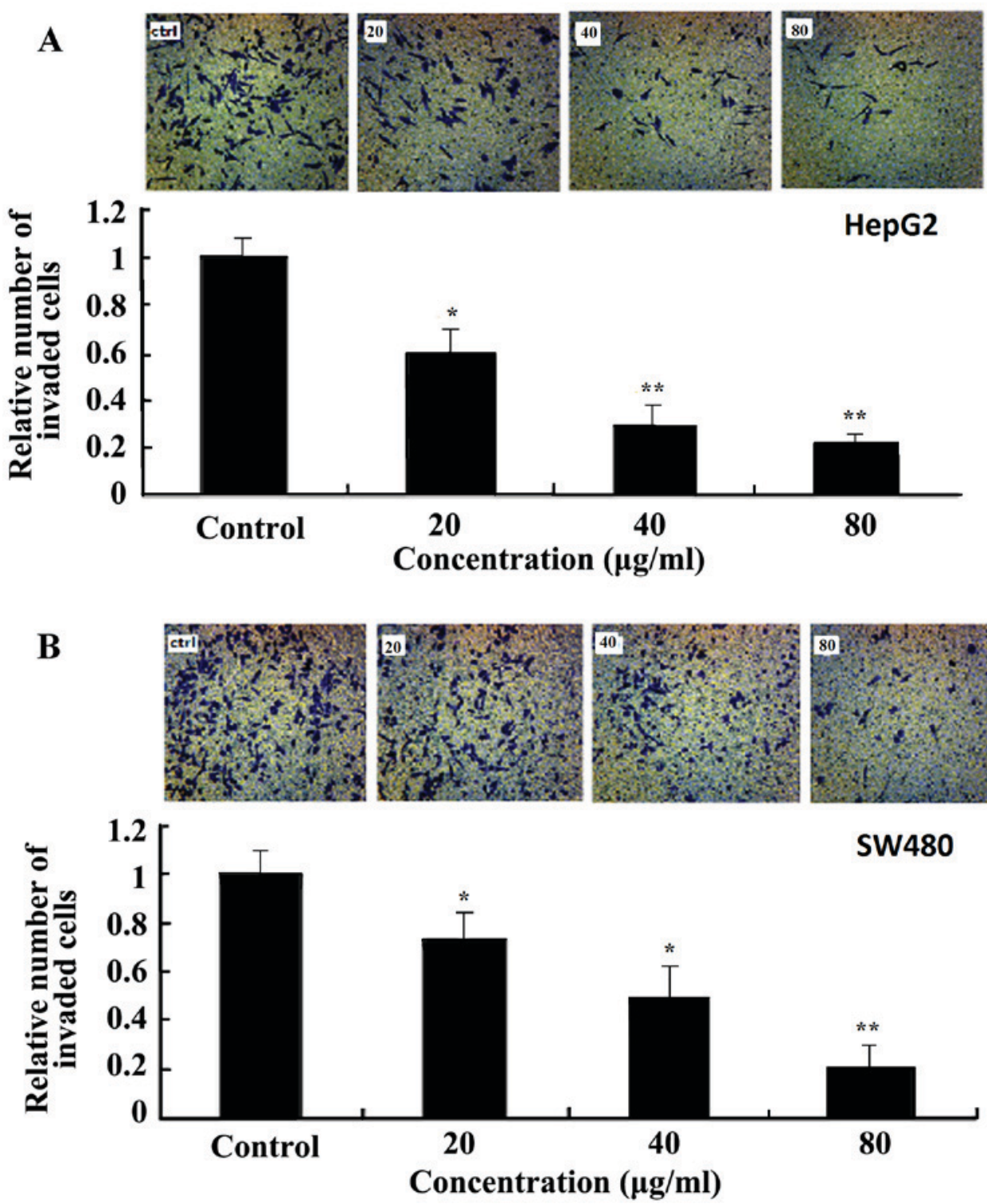

Figure 4. Ginkgol C17:1 inhibits cancer cell invasion. The invasion of (A) HepG2 and (B) SW480 cells was detected using peridium Matrigel on the bottom of Transwell Boyden chambers following treatment with dimethyl sulfoxide alone (control) or various concentrations of Ginkgol C17:1 for 24 h. Invaded cells were examined under a light microscope (magnification, x200). Data are presented as the mean \pm standard deviation of three independent experiments, each performed in duplicate. ${ }^{*} \mathrm{P}<0.05,{ }^{* *} \mathrm{P}<0.01$ vs. the control cells.

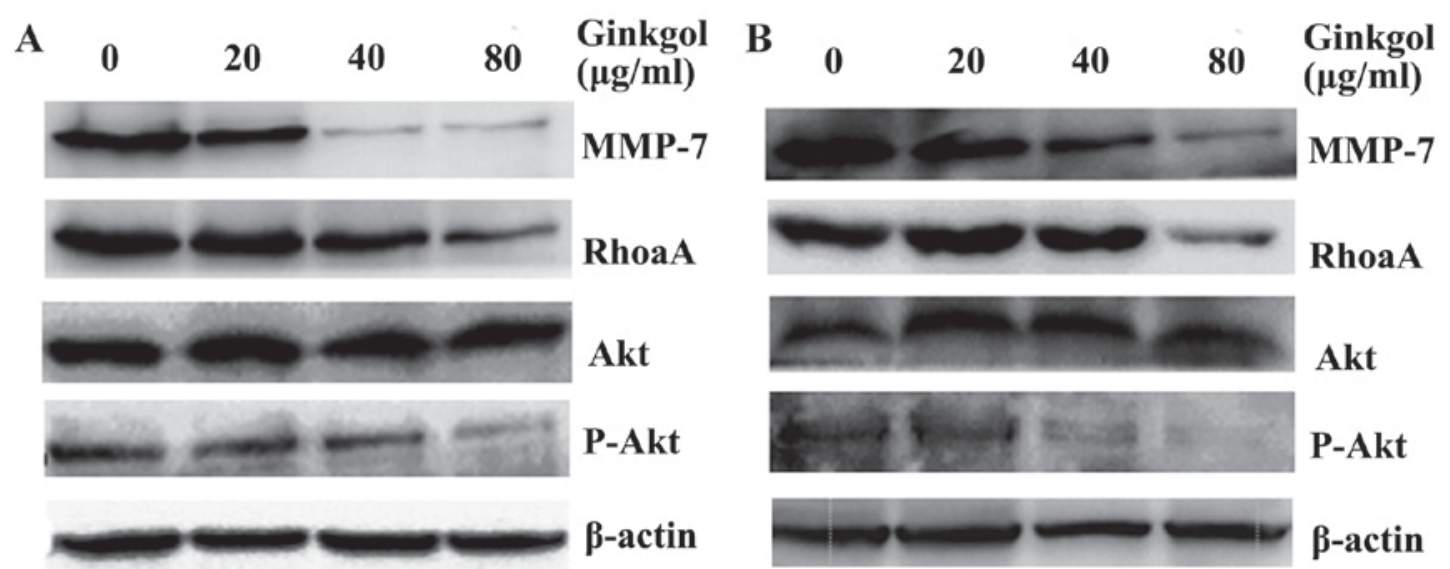

Figure 5. Ginkgol C17:1 affects the protein levels of MMP-7, RhoA and p-Akt in cancer cells. Subsequent to the treatment of (A) HepG2 and (B) SW480 cells with 20, 40 or $80 \mu \mathrm{g} / \mathrm{ml} \mathrm{Ginkgol} \mathrm{C17:1} \mathrm{for} 24 \mathrm{~h}$, whole cell extracts were prepared for the detection of the protein levels of MMP-7, RhoA, Akt and p-Akt by western blotting. $\beta$-actin expression served as a loading control. MMP, matrix metalloproteinase; RhoA, ras homolog gene family, member A; $\mathrm{p}$, phosphorylated; Akt, protein kinase B. 
Ginkgol C17:1 exhibited stronger thermal stability compared with GAs and exerted stronger anticancer effects compared with the monomers of Ginkgol and GAs, with respect to the apoptosis of tumor cells (9).

In the present study, the effects of Ginkgol C17:1 on the biological behaviors of human tumor cells were systematically investigated, in terms of cell proliferation, migration and invasion. Consistent with a previous study using other cancer cells (9), the present study found a dose-dependent inhibition of cell proliferation in human hepatoma carcinoma HepG2 cells and colon cancer SW480 cells. In addition, the results of the present study revealed that Ginkgol C17:1 inhibited the cell migration and invasion capabilities of HepG2 and SW480 cells in a dose-dependent manner.

The protein expressions of RhoA, MMP-7, Akt, and p-Akt were analyzed by western blotting to investigate the underlying mechanisms of the inhibitory effects of Ginkgol C17.1 on cancer cells. The results revealed that, subsequent to a $24 \mathrm{~h}$ treatment with Ginkgol C17:1, the expressions of RhoA and MMP-7 proteins were markedly reduced. Although the total amount of Akt protein remained unchanged, the expression of p-Akt was markedly decreased.

RhoA activation is associated with invasive growth and metastasis. The best known effector of RhoA is Rho kinase (ROCK), which appears to serve a key role in regulating the force and velocity of actomyosin crossbridging in smooth muscle and non-muscle cells by inhibiting the myosin phosphatase-mediated dephosphorylation of the regulatory chain of myosin II (19). The inhibition of RhoA reduces the level of tumor cell invasion and metastasis, and these effects may be mediated by the RhoA target protein ROCK (20). Since RhoA protein expression decreased subsequent to Ginkgol C17:1 treatment, the present study hypothesized that Ginkgol C17:1 suppresses the development and growth of tumors by inhibiting the RhoA/ROCK pathway.

MMP-7 is associated with invasive tumor growth and distant metastasis in several types of cancer (21). Although MMP-7 is rarely expressed in normal tissues, the level of expression rises during the malignant transformation of tumors, inflammatory diseases (22) and epithelial-mesenchymal transition (23); thus serving an important role in the process of malignancy (24). MMP-7 markedly enhances chondrosarcoma cell motility and invasion due to its upregulation in response to stress exposure, which may promote lung colonization of chondrosarcomas in vivo (25). MMP-7 was also found to be an indicator of poor survival and a high recurrence rate in patients with colorectal cancer (26). In the present study, the marked decrease in the level of MMP-7 following Ginkgol C17:1 treatment confirmed that Ginkgol C17:1 inhibits the migration and invasion of tumor cells by inhibiting MMP-7.

The PI3K/Akt signaling pathway has been found to serve an important role in the survival, proliferation and apoptosis of tumor cells $(27,28)$. p-Akt-positive expression is significantly associated with distant metastasis and unfavorable prognosis $(29,30)$. While the protein expression of total Akt in cancer cells did not change following treatment with Ginkgol C17:1 in the present study, the level of p-Akt was markedly decreased, confirming the inhibitory effect of Ginkgol C17:1 on the activation of the PI3K/Akt signaling pathway.
In conclusion, the present study investigated the inhibitory effect of Ginkgol C17:1 on cancer cell proliferation and migration and revealed that Ginkgol C17:1 inhibited the invasion capacity of hepatocellular and colon cancer cells. The underlying mechanisms for the suppression of tumor biological behaviors may be associated with the reduced activities of the RhoA/ROCK, MMP-7 and PI3K/Akt pathways. These results indicate that Ginkgol C17:1 maybe a novel candidate for cancer therapy. Additional investigation is required, for example, to understand the interaction of Ginkgol C17:1 with the cancer cells and the subsequent cascade with respect to altered cancer biology.

\section{Acknowledgements}

The present study was supported by grants from the National Natural Science Foundation of China (grant no. 81372404), the Specialized Research Fund for Senior Personnel Program of Jiangsu University (grant no. 11JDG129), the Postdoctoral Foundation of China (grant no. 2012M521018) and the Postdoctoral Foundation of Jiangsu province (grant no. 1201025B).

\section{References}

1. Forner A, Llovet JM and Bruix J: Hepatocellular carcinoma. Lancet 379: 1245-1255, 2012.

2. Vermorken JB and Specenier P: Optimal treatment for recurrent/metastatic head and neck cancer. Ann Oncol 21 (Suppl 7): vii252-vii261, 2010.

3. Sawicka E, Mirończuk A, Wojtukiewicz MZ and Sierko E: Chemoradiotherapy for locally advanced pancreatic patients: is it still an open question? Contemp Oncol (Pozn) 20: 102-108, 2016.

4. van Beek TA and Montoro P: Chemical analysis of Ginkgo biloba leaves and extracts, and phytopharmaceuticals. J Chromatogr A 1216: 2002-2032, 2009.

5. Boonsai P, Phuwapraisirisan P and Chanchao C: Antibacterial activity of a cardanol from Thai Apis mellifera Propolis. Int $\mathbf{J}$ Med Sci 11: 327-336, 2014.

6. Meng ZL, Wei Y, Xu DM, Hao SH and Hu JY: Effect of 2-allylphenol against Botrytis cinerea Pers., and its residue in tomato fruit. Crop Protection 26: 1711-1715, 2007.

7. Shi QT, Liu H, Zhang YZ, Gu S and Liu LY: Study on antifeeding activity of ginkgo phenol to cannage caterpillar. Biomass Chem Engineer 43: 13-16, 2009.

8. Trevisan MT, Pfundstein B, Haubner R, Würtele G, Spiegelhalder B, Bartsch H and Owen RW: Characterization of alkyl phenols in cashew (Anacardium occidentale) products and assay of their antioxidant capacity. Food Chem Toxicol 44: 188-197, 2006.

9. Yang XM, Wang YF, Li YY and Ma HL: Thermal stability of ginkgolic acids from Ginkgo biloba and the effects of ginkgol C17:1 on the apoptosis and migration of SMMC7721 cells. Fitoterapia 98: 66-76, 2014.

10. Tan WH, Shen ZB, Wang CZ and Yu Q: Isolation and identification of alkylphenols from Ginkgo biloba leaves. Chem Ind Forest Prod 21: 1-6, 2001.

11. Lee JS, Cho YS, Park EJ, Kim JW, Oh WK, Lee HS and Ahn JS: Phospholipase Cgammal inhibitory principles from the sarcotestas of Ginkgo biloba. J Nat Prod 61: 867-871, 1998.

12. Wang YF, Yang XM, Li YY, Huang BZ, Guo CY and Xing CH: Inhibitory effect of ginkgols on SMMC-7721 liver cancer cells in vitro and liver cancer H22-braring mice in vivo. J Jiangsu Univ (Med Edit) 23: 233-237, 2013.

13. Law AY and Wong CK: Stanniocalcin-2 promotes epithelial-mesenchymal transition and invasiveness in hypoxic human ovarian cancer cells. Exp Cell Res 316: 3425-3434, 2010.

14. Kim KH, Cho YS, Park JM, Yoon SO, Kim KW and Chung AS: Pro-MMP-2 activation by the PPARgamma agonist, ciglitazone, induces cell invasion through the generation of ROS and the activation of ERK. FEBS Lett 581: 3303-3310, 2007. 
15. Singh B, Kaur P, Gopichand, Singh RD and Ahuja PS: Biology and chemistry of Ginkgo biloba. Fitoterapia 79: 401-418, 2008.

16. Liu ZH and Zeng S: Cyctotoxicity of ginkgolic acids in HepG2 cells and primary rat hepatocytes. Toxicol Lett 187: 131-136, 2009.

17. Zhou C, Li X, Du W, Feng Y, Kong X, Li Y, Xiao L and Zhang P: Antitumor effects of ginkgolic acids in human cancer cell occur via cell cycle arrest and decrease the $\mathrm{Bcl}-2 / \mathrm{Bax}$ ratio to induce apoptosis. Chemotherapy 56: 393-402, 2010.

18. Sukumari-Ramesh S, Singh N, Jensen MA, Dhandapani KM and Vender JR: Anacardic acid induces caspase-independent apoptosis and radiosensitizes pituitary adenoma cells. J Neurosurg 114: 1681-1690, 2011.

19. Wettschureck N and Offermanns S: Rho/Rho-kinase mediated signaling in physiology and pathophysiology. J Mol Med (Berl) 80: 629-638, 2002.

20. Kamai T, Yamanishi T, Shirataki H, Takagi K, Asami H, Ito Y and Yoshida K: Overexpression of RhoA, Rac1, and Cdc42 GTPases is associated with progression in testicular cancer. Clin Cancer Res 10: 4799-4805, 2004.

21. Han JC, Li XD, Du J, Xu F, Wei YJ, Li HB and Zhang YJ: Elevated matrix metalloproteinase-7 expression promotes metastasis in human lung carcinoma. World J Surg Oncol 13: 5, 2015.

22. Meng F, Yang H, Jack C, Zhang H, Moller A, Spivey D, Page RC, Tierney DL and Crowder MW: Biochemical characterization and zinc binding group (ZBGs) inhibition studies on the catalytic domain of MMP7 (cdMMP7). J Inorg Biochem 165: 7-17, 2016.
23. Simic P, Williams EO, Bell EL, Gong JJ, Bonkowski M and Guarente L: SIRT1 suppresses the epithelial-to-messenchymal transition in cancer and organ fibrosis. Cell Rep 3: 1175-1186,2013.

24. Li KJ, Hua G and Li H: Mechanism research progress and protection of light skin damage. J Dermatol Venereol 32: 24-27, 2010.

25. Guan PP, Yu X, Guo JJ, Wang Y, Wang T,LiJY,Konstantopoulos K, Wang ZY and Wang P: By activating matrix metalloproteinase-7, shear stress promotes chondrosarcoma cell motility, invasion and lung colonization. Oncotarget 6: 9140-9159. 2015.

26. Ahmed Haji Omar A, Haglund C, Virolainen S, Häyry V, Atula T, Kontio R, Salo T, Sorsa T and Hagström J: MMP-7, MMP-8, and MMP-9 in oral and cutaneous squamous cell carcinomas. Oral Surg Oral Med Oral Pathol Oral Radiol 119: 459-467, 2015.

27. Liu Y, Zhang Y, Jia K, Dong Y and Ma W: Metformin inhibits the proliferation of A431 cells by modulating the PI3K/Akt signaling pathway. Exp Ther Med 9: 1401-1406, 2015.

28. Itoh N, Semba S, Ito M, Takeda H, Kawata S and Yamakawa M: Phosphorylation of Akt/PKB is required for suppression of cancer cell apoptosis and tumor progression in human colorectal carcinoma. Cancer 94: 3127-3134, 2002.

29. Meuillet EJ: Novel Inhibitors of AKT: Assessment of a different approach targeting the pleckstrin homology domain. Curr Med Chem 18: 2727-2742, 2011.

30. Xia S, Feng Z, Qi X, Yin Y, Jin J, Wu Y, Wu H, Feng Y and Tao M: Clinical implication of Sox 9 and activated Akt expression in pancreatic ductal adenocarcinoma. Med Oncol 32: 358 2015. 